\title{
Mineralocorticoid Receptor
}

National Cancer Institute

\section{Source}

National Cancer Institute. Mineralocorticoid Receptor. NCI Thesaurus. Code C17312.

Mineralocorticoid receptor (984 aa, $107 \mathrm{kDa}$ ) is encoded by the human NR3C2 gene.

This protein is involved in the modulation of mineralcorticoid and glucocorticoiddependent gene transcription. 